\title{
Overview of Biological and Chemical Conditions on the Flemish Cap with Comparisons of the Grand Banks Shelf and Slope Waters During 1996-2003
}

\author{
G. L. Maillet, P. Pepin, J. D. C. Craig, S. Fraser, and D. Lane \\ Department of Fisheries and Oceans, P. O. Box 5667 \\ St. John's, NL, Canada A1C 5X1
}

Maillet, G. L., P. Pepin, J. D. C. Craig, S. Fraser, and D. Lane. 2005. Overview of biological and chemical conditions on the Flemish Cap with comparisons of the Grand Banks shelf and slope waters during 1996-2003. J. Northw. Atl. Fish. Sci., 37: 29-45. doi:10.2960/J.v37.m561

\begin{abstract}
The seasonal dynamics of nutrients, phytoplankton and zooplankton populations are described for the period 1996-2003 along an oceanographic section extending from the inshore across the Grand Banks (GB) and Flemish Cap (FC). We present evidence of enhanced inventories of nitrate and silicate and biological productivity on the FC and adjacent Slope (SL) waters compared to the Grand Banks Shelf (GBS). The seasonal occupations along the oceanographic section indicated persistent and enhanced inventories of nitrate and silicate and the potential for higher nutrient fluxes in the SL water and the FC, in contrast to the GBS. The shallow water of the Flemish Cap combined with the proximity of large-scale oceanic circulation around the Bank, including the Labrador Current (LC) and North Atlantic Current (NAC) which generate an anticyclonic gyre, elevate water temperatures, and entrain NAC water rich in inorganic dissolved nutrients, that act to enhance primary and secondary production. The southerly flow of the LC through the Flemish Pass and northeastern flank of the FC act to transport subarctic copepod species from northern regions to the FC and SL waters. These subarctic Calanoid copepods tend to be much larger in body size compared to the community observed on the GBS and contribute to a significant increase in biomass on the FC and SL waters. Fluxes of "new" nitrogen (principally nitrate) delivered to the FC and SL waters appear to support significant levels of "new" primary productivity resulting in a higher productive capacity compared to the adjacent GBS environment. The biomass estimates obtained from the dominant copepod genera from the Continuous Plankton Recorder (CPR) survey and Atlantic Zonal Monitoring Program (AZMP) provide evidence in support of the hypothesis of higher primary productivity that enhances secondary production over the FC and adjacent waters.

Key words: Flemish Cap, Grand Banks, biological and chemical conditions, biological oceanography.
\end{abstract}

\section{Introduction}

The Flemish Cap (FC), located east of the Grand Banks (GB) of Newfoundland centered at $47^{\circ} \mathrm{N}$ and $45^{\circ} \mathrm{W}$, is thought to have high primary $\left(1^{\circ}\right)$ and secondary $\left(2^{\circ}\right)$ productivity in support of the abundant invertebrate and fish populations documented in this area (see this volume). The $1^{\circ}$ and $2^{\circ}$ production cycles on the $\mathrm{FC}$ are known to be seasonal in nature (Anderson, 1990), yet few studies have investigated the basis for enhanced productivity in this region and interannual variability in the standing stocks of the lower trophic levels.

The hydrography of the FC and surrounding waters has been described and indicate that two major current systems dominate the circulation and water mass properties (Colbourne and Foote, 2000). The southward flowing Labrador Current (LC) through the Flemish Pass and east and southeast around the northern and eastern slopes, transport cold-low salinity Labrador slope water onto the
FC. The northward flowing North Atlantic Current (NAC) transports warmer, high salinity water to the northeast along the southeast slope of the GB and FC. The close proximity of the $\mathrm{NAC}$ to the $\mathrm{FC}$, with water temperatures in excess of $4^{\circ} \mathrm{C}$, elevates the average temperature on the FC in contrast to Grand Banks Shelf (GBS), which is separated from the FC by the cold (ca. $3-4^{\circ} \mathrm{C}$ ) southward flow of the LC (Colbourne and Foote, 2000). Variation in the thermal environment is thought to influence the distribution and biological production of Newfoundland and Labrador Shelf and Slope (SL) waters, given the overlap between arctic, boreal, and temperate waters. The elevated temperatures on the FC result in ice-free conditions, which may allow longer growing seasons and permit higher rates of growth compared to cooler conditions prevailing on the Grand Banks (GB) and along the western slope (SL) waters.

The supply of nutrients to the euphotic zone is of central importance to autotrophic organisms, principally 
phytoplankton, forming the base of the food chain for planktonic and benthic heterotrophs. The nutrients utilized by phytoplankton are predominately formed at depth through microbial processes and transported back to the photosynthetically active part of the water column by physical processes such as tidal and wind-induced vertical mixing, winter overturning and other upwelling processes (Petrie and Yeats, 2000). In certain regions, advection of nutrient rich surface waters might be of greater importance than local surface nutrient replenishment processes. This paper presents seasonal distributions and concentrations of inorganic nutrients (nitrate and silicate), temperature and salinity profiles and indices of water column stability, along with distribution and abundance of major phytoplankton and zooplankton groups for the $\mathrm{FC}$ and nearby GB and SL waters from 1996-2003. The available information include the period from spring through autumn, allowing us to develop a better understanding of important biotic and abiotic features of this region and their potential influence on the production cycle. We utilize data from various sources in order to characterize the biological, chemical, and physical conditions along an oceanographic section extending from the Newfoundland coast to the FC and SL waters. These sources include data collected as part of the Northern Cod Science Program $\left(\mathrm{NCSP}^{1}\right)$, the AZMP $^{2}$ conducted by the Department of Fisheries and Oceans (Canada), as well as information gathered by the $\mathrm{CPR}^{3}$ Survey and SeaWiFS ocean colour imagery from the Bedford Institute of Oceanography ${ }^{4}$ (Department of Fisheries and Oceans Canada).

\section{Materials and Methods}

Protocols for the collection and processing of CTD, nutrients, distribution and abundance patterns of phytoplankton and zooplankton populations as part of the AZMP and similar plankton monitoring in the NCSP, are provided in Mitchell et al., 20025. Physical indices to measure water-column stability included the stratification index (SI), which is defined as the difference in sigma-t values between $50 \mathrm{~m}$ and $5 \mathrm{~m}$ divided by $45 \mathrm{~m}$ (see Craig et al., MS 2001; Craig and Colbourne, MS 2002), and mixed layer depth (MLD), taken as the depth centre of the pycnocline (layer where density changes rapidly with depth). Sample collections for nutrient distributions from both the NCSP and AZMP sources are based on seasonal surveys listed in Table 1, and nominal sampling locations across the section are provided in Fig. 1. The timing of the seasonal surveys were generally within a \pm 2 week window, the exceptions being the spring survey conducted in mid-May in 1997 and the autumn occupations which tended to vary by \pm 3 weeks carried out during the month of November. The CPR survey identifies roughly 400 different phytoplankton and zooplankton taxa. The majority of the phytoplankton taxa enumerated by the CPR consist of hard siliceous cells of diatoms and the armoured dinoflagellates. Many of the smaller flagellate forms that are abundant numerically, are not enumerated in the CPR. The CPR data analyzed in this report extend from 1961 to 2002 with an intervening gap from 1979 to 1990 . The sampling distribution was uneven for both spatial and temporal scales due to the nature of opportunistic sampling with ships of opportunity, variation in shipping routes, and CPR funding (see Fig. 2 for location and distribution of CPR data). Measurement of primary production was conducted using a custom-built photosynthetron (CHPT Inc., Lewes, DE, USA, see Lewis and Smith (1983) for a general description of the system and methods). We estimated daily water-column integrated primary production using the algorithm (numerical integration of spectral model) from the software for calculation of primary production in the oceanic water column as described by Platt and Sathyendranath $(2000)^{6}$.

\section{Results}

\section{Water Column Properties and Structure}

Significant differences in the thermohaline properties are apparent across the section during the three sampling periods in 2003 (Fig. 3). The seasonal occupations of the section show elevated temperature and salinity over the FC and adjacent SL waters in contrast to lower salinity and temperature on the GBS. The location of the LC in the Flemish Pass region showing sharp thermohaline gradients marks the boundary between water masses on the GBS and FC. Stratification (SI) and mixed layer depth (MLD) indices vary seasonally across the section. The seasonal averaged values of the SI were relatively low (0.001-0.003 $\mathrm{kg} \mathrm{m}^{-4}$ ) during spring, although higher values observed on the GBS and SL waters suggests stratification begins

\footnotetext{
1 http://www.usglobec.org/reports/rep2/rep2.chapter4.html.

2 http://www.meds-sdmm.dfo-mpo.gc.ca/zmp/main_zmp_e.html.

3 http://192.171.163.165/.

4 http://www.mar.dfo-mpo.gc.ca/science/ocean/ias/remotesensing.html.

5 http://www.meds-sdmm.dfo-mpo.gc.ca/zmp/docs_e.html.

6 http://www.ioccg.org/data/software.html.
} 
TABLE 1. Summary of biological and chemical sampling missions and collection dates across the Flemish Cap oceanographic section during 1996-2003.

\begin{tabular}{|c|c|}
\hline Vessel and Trip \# & Dates \\
\hline Parizeau 012 & 28-30 April 1996 \\
\hline Parizeau 013 & 17-20 July 1996 \\
\hline Parizeau 014 & 14-17 May 1997 \\
\hline Parizeau 015 & 11-13 July 1997 \\
\hline Teleost 062 & 27-29 April 1998 \\
\hline Teleost 068 & 21-24 July 1998 \\
\hline Hudson 003 & 22 November 1999 \\
\hline Teleost 080 & 17-20 July 1999 \\
\hline Teleost 302 & 25 April 25-2 May 2000 \\
\hline Teleost 305 & 15-18 July 2000 \\
\hline Hudson 004 & 4-7 November 2000 \\
\hline Teleost 352 & 25-29 April 2001 \\
\hline Teleost 356 & 14-15 July 2001 \\
\hline Hudson 001 & 19-22 November 2001 \\
\hline Teleost 403 & 25-28 April 2002 \\
\hline Teleost 408 & 13-15 July 2002 \\
\hline Hudson 449 & 13-17 November 2002 \\
\hline Teleost 462 & 23-26 April 2003 \\
\hline Teleost 466 & 22-24 July 2003 \\
\hline Hudson 507 & 22-27 November 2003 \\
\hline
\end{tabular}

earlier than on the FC (Table 2). The MLD deepened on the FC (e.g. $75 \mathrm{~m}$ ), compared to a value of $60 \mathrm{~m}$ observed on the GBS and SL during the early production cycle. The SI increased by an order of magnitude during summer to $0.03-0.04 \mathrm{~kg} \mathrm{~m}^{-4}$, while the MLD decreased to $16 \mathrm{~m}$, with little variability across the section. While the level of stability as measured by the SI remained relatively high from the summer into the autumn period on the GBS, more extensive breakdown of water column structure is observed on the FC and SL waters (Table 2).

\section{Biological and Chemical Conditions - Seasonal Variability in Major Nutrients}

Since dedicated surveys were initiated in 1996, the vertical distribution of nitrate across the section shows a marked change at the Shelf break with lower concentrations observed over the GBS compared to elevated values over the FC and SL waters (Fig. 4). The vertical distribution of nitrate over the entire extent of the GBS showed signs of being depleted $\left(<1 \mathrm{mmol} \mathrm{m}^{-3}\right)$ in the upper $50 \mathrm{~m}$ during spring surveys (late April), an indication of biological uptake taking place several weeks earlier. The average concentration of nitrate and silicate in the upper $75 \mathrm{~m}$ layer over the SL and FC exceed $5 \mathrm{mmol} \mathrm{m}^{-3}$ compared to

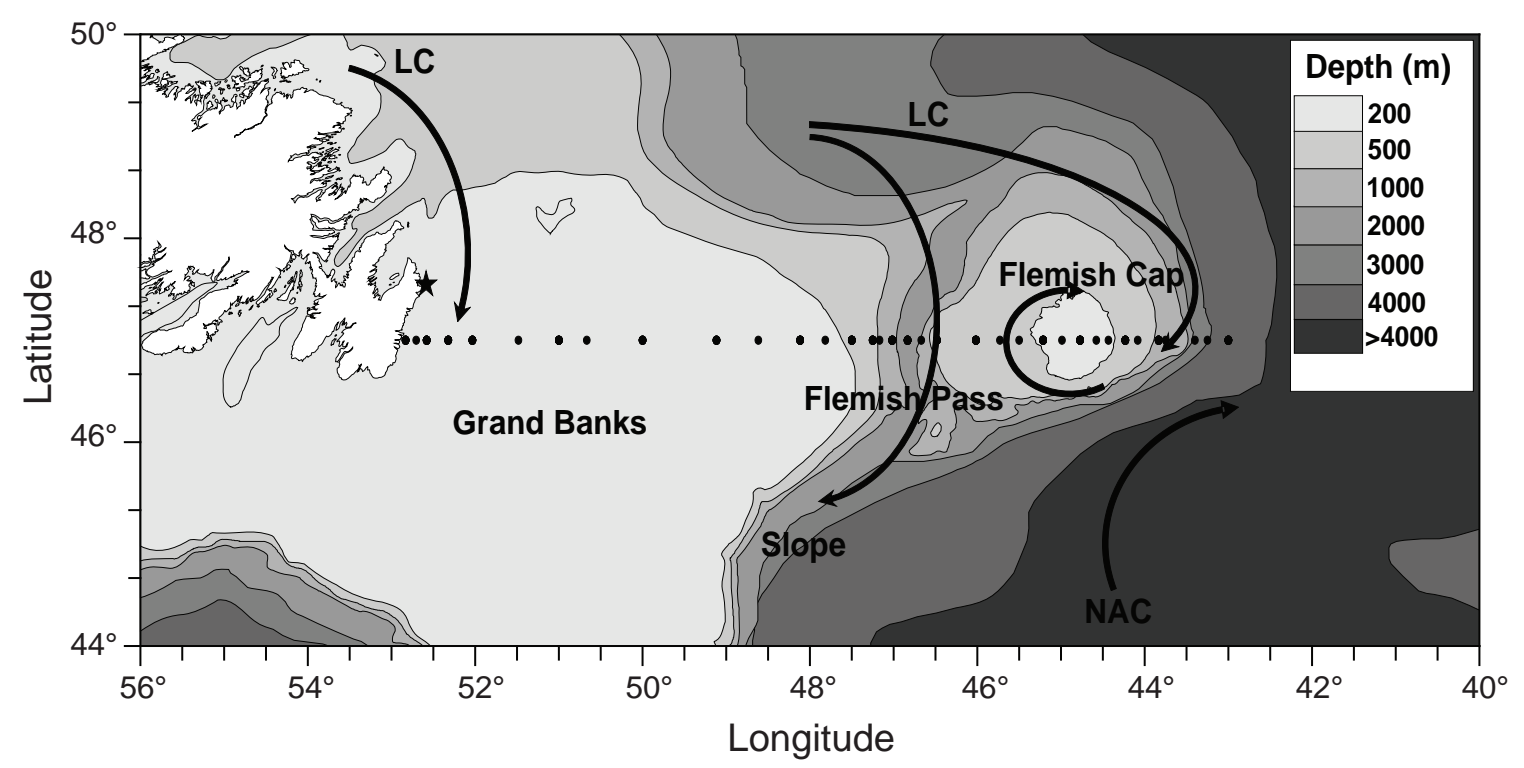

Fig. 1. Map of oceanographic section across the Grand Banks Shelf and Flemish Cap showing nominal sample station locations along with the general bathymetry and circulation features. The section is located along the $47^{\circ} \mathrm{N}$ latitude. The section was divided into Shelf $\left(47^{\circ} \mathrm{N}\right.$ Latitude $52^{\circ} 49.9^{\prime} \mathrm{W}$ Longitude $-47^{\circ} 15.0^{\prime} \mathrm{W},<500 \mathrm{~m}$; Flemish Pass and Slope waters (henceforth referred to as Slope waters) $47^{\circ} \mathrm{N} 47^{\circ} 10.1^{\prime} \mathrm{W}-46^{\circ} \mathrm{N} 40.2^{\prime} \mathrm{W}$ and $43^{\circ} \mathrm{N}$ $50.0^{\prime} \mathrm{W}-43^{\circ} \mathrm{N} 00.0^{\prime} \mathrm{W},>500 \mathrm{~m}$; and Flemish Cap $\left(47^{\circ} \mathrm{N} 46^{\circ} 29.0^{\prime} \mathrm{W}-44^{\circ} \mathrm{N} 05.0^{\prime} \mathrm{W},<500 \mathrm{~m}\right)$. Location of inshore fixed coastal station (Station 27) indicated by the star. The general locations of the inshore and offshore portion of the Labrador (LC) and North Atlantic Currents (NAC) and the anticyclonic gyre that forms around the Flemish Cap are provided. 


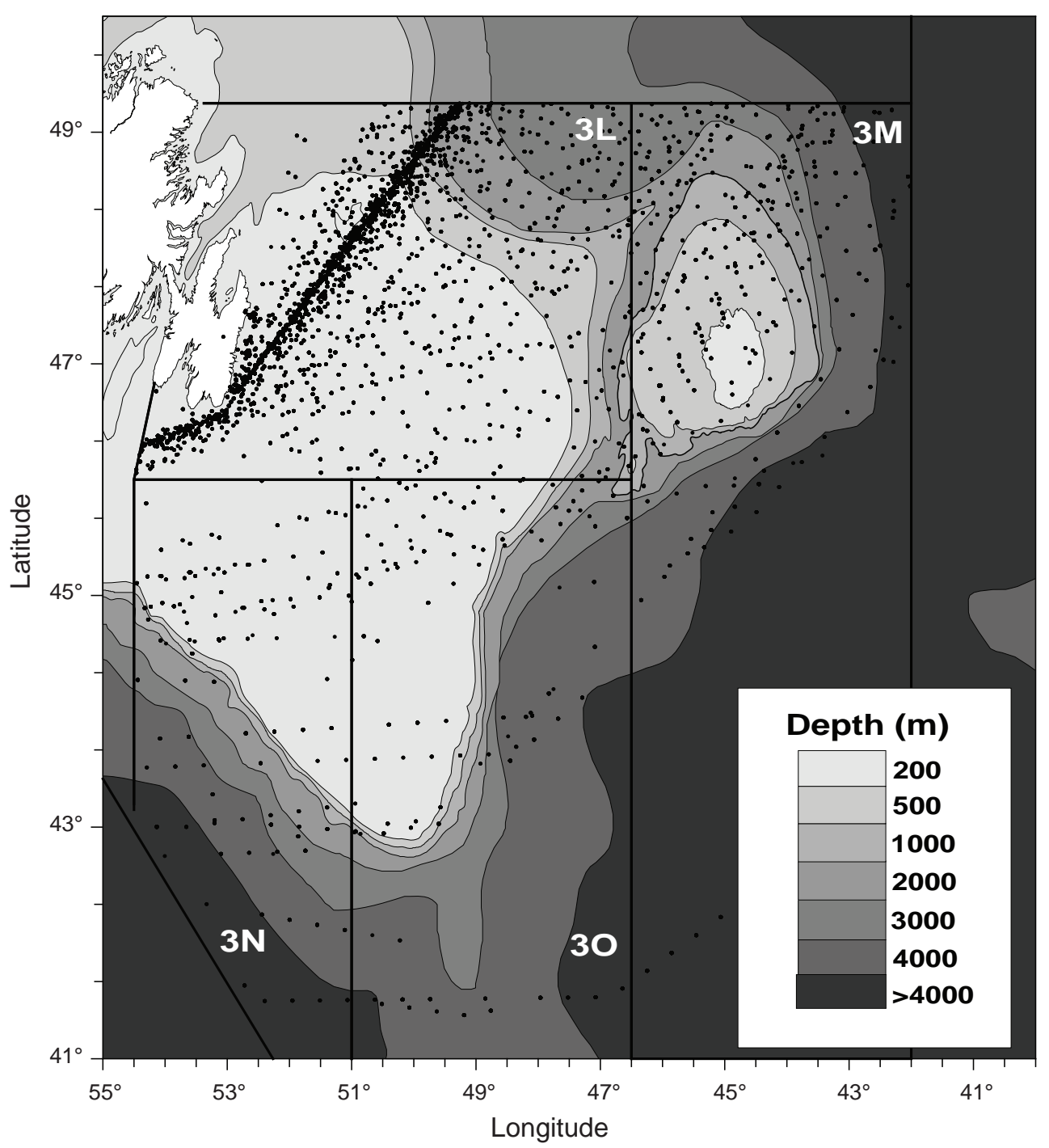

Fig. 2. Overlay of CPR stations in the Northwest Atlantic from 1961 to 2002. Each dot represents the centre of an $18.5 \mathrm{~km}$ tow section in NAFO Subdiv. 3LNO (Grand Banks) and Div. 3M (Flemish Cap). Note the concentrated sampling along standard CPR routes.

$<3 \mathrm{mmol} \mathrm{m}^{-3}$ on the GBS (Table 3). Vertical integration of these dissolved inorganic nutrients in this upper layer indicated 2-fold higher levels over the FC and SL waters compared to the GBS during spring (Table 4).

Despite the higher nutrient levels over the FC and SL waters, the distribution of phytoplankton biomass, as revealed from the chlorophyll $a$ distributions, indicated that most of the biomass present during the spring occupations is concentrated over the central Shelf and Shelf break (Fig. 5). Concentrations of chlorophyll $a$ in the upper 75 $\mathrm{m}$ were highest during the spring occupations, averaging between $2-3 \mathrm{mg} \mathrm{m}^{-3}$ across the section (Table 3 ). The inventories (vertical integration) of chlorophyll $a$ in the upper layer are slightly higher on average over the GBS compared to the FC and SL waters during spring (Table 4). The intensity of the spring bloom, as judged from the distribution of chlorophyll $a$ biomass across the section during the study period, appears to have declined in recent years (Fig. 5). Although the timing of the spring occupations across the section were relatively consistent during the study period (Table 1), variability in the timing of the spring bloom could also contribute to the observed decline in chlorophyll $a$ biomass due to aliasing. The summer occupations across the section are typically characterized by further depletion of nutrients due to biological uptake and enhanced density stratification limiting the transport of nutrients from depth. The average concentration of 


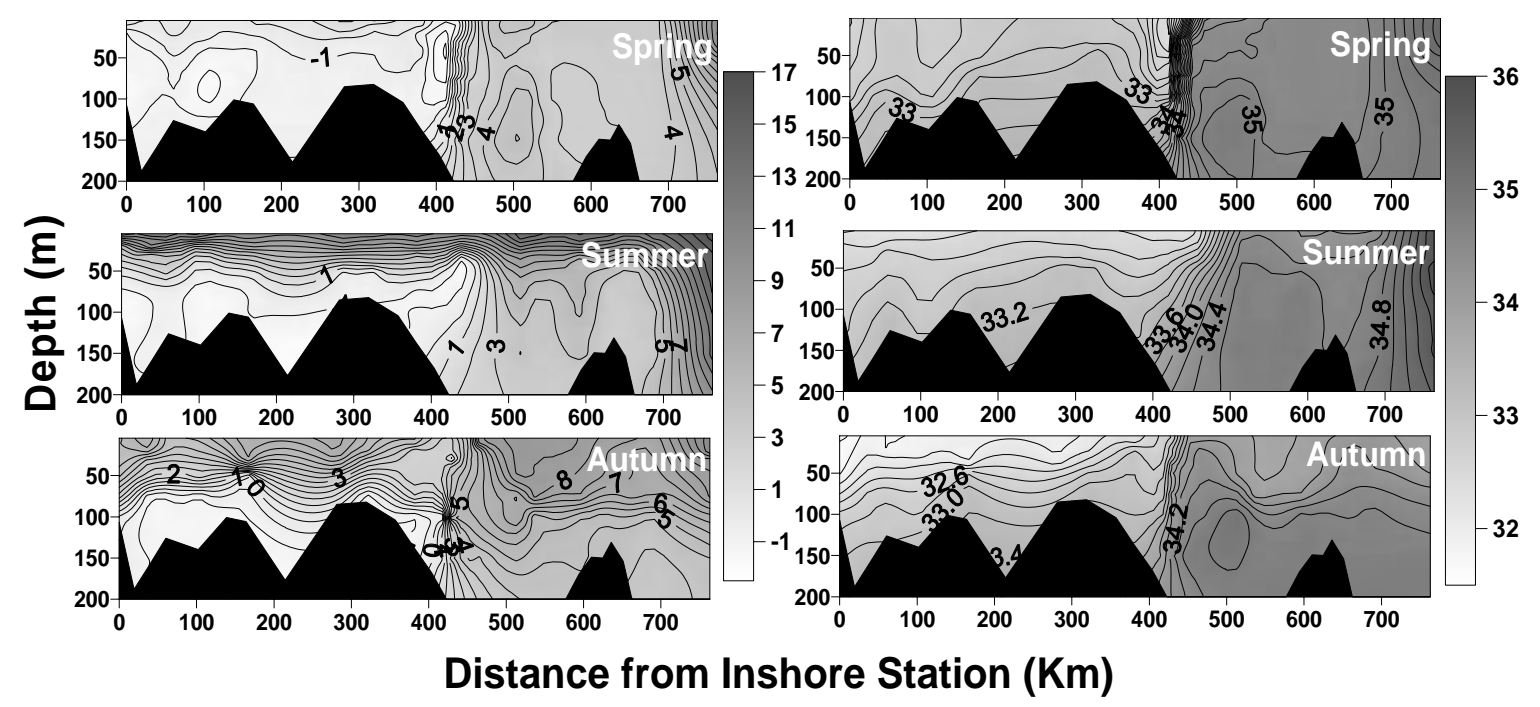

Fig. 3. Seasonal vertical profiles of temperature (left panels; ${ }^{\circ} \mathrm{C}$ ) and salinity (right panels; PSU) in the upper $200 \mathrm{~m}$ versus distance from the coastal station across the Flemish Cap section during 2003. Bottom bathymetry shown in black.

TABLE 2. Seasonal average $( \pm \mathrm{SD})$ of the stratifi-cation index (SI; density difference between 50 and $5 \mathrm{~m}$ divided by $45 \mathrm{~m}$ ) and mixed layer depth (MLD; determined from the depth centre of the pynocline) during 2000-04 along the Grand Bank Shelf(GBS), Flemish Cap (FC) and Slope (SL) waters.

\begin{tabular}{llcc}
\hline \hline Season & Location & $\begin{array}{c}\text { Avg S.I. } \\
\left(\mathrm{Kg} \mathrm{m}^{-4}\right)\end{array}$ & $\begin{array}{c}\text { Avg. MLD } \\
(\mathrm{m})\end{array}$ \\
\hline \multirow{2}{*}{ Spring } & GBS & $0.0031 \pm 0.002$ & $64.3 \pm 15.2$ \\
& SL & $0.0034 \pm 0.002$ & $57.9 \pm 15.0$ \\
\multirow{5}{*}{ Summer } & FC & $0.0013 \pm 0.001$ & $75.4 \pm 16.7$ \\
& GBS & $0.0341 \pm 0.003$ & $15.6 \pm 2.6$ \\
& SL & $0.0357 \pm 0.006$ & $16.4 \pm 1.7$ \\
& FC & $0.0317 \pm 0.006$ & $15.6 \pm 2.3$ \\
& GBS & $0.0181 \pm 0.007$ & $44.1 \pm 2.4$ \\
& SL & $0.0085 \pm 0.005$ & $65.7 \pm 16.9$ \\
& FC & $0.0070 \pm 0.004$ & $75.4 \pm 10.4$ \\
\hline
\end{tabular}

nitrate and silicate in the upper layer was $<2 \mathrm{mmol} \mathrm{m}^{-3}$ on the GBS but exceeded this concentration on the FC and SL waters (Table 3). The SL waters showed the largest inventories of inorganic nutrients, followed by the FC, and the GBS (Table 4). The nitracline depth which forms prominently during summer, and defined as the depth at which nitrate exceeds $0.5 \mathrm{mmol} \mathrm{m}^{-3}$, is deeper across the GBS, in contrast to shallower depths over the FC and SL waters (Table 4). The nitrate isolines appear dome-shaped and sloped at depths in excess of $50 \mathrm{~m}$ over the western and eastern SL waters surrounding the FC, in contrast to horizontal isolines across the GBS (Fig. 4).
The summer concentrations of chlorophyll $a$ are low compared to the spring period, although evidence of localized sub-surface blooms are apparent across the section (Fig. 5). In general, deep chlorophyll $a$ max layers (DCM) are observed to form on the GBS, FC, and eastern SL waters. The depth of the DCM layers appears to be near the nitracline across the section (Fig. 4). The summer chlorophyll $a$ concentrations in the upper $75 \mathrm{~m}$ layer were $<1 \mathrm{mg} \mathrm{m}^{-3}$ across the section (Table 3 ). The summer chlorophyll $a$ inventories in the upper layer were greater on the FC and SL respectively, compared to lower levels on the GBS (Table 4).

The autumn occupations across the section continue to show depletion of nitrate to concentrations $\leq 1 \mathrm{mmol}$ $\mathrm{m}^{-3}$ in the upper water column, but enhanced nitrate levels over the FC and SL waters at depth compared to the GBS (Fig. 4). Evidence of strong vertical gradients in nitrate observed during the spring and summer occupations are also seen during the autumn (Fig. 4). The nitracline also was deeper across the GBS compared to shallower depths across the FC and SL waters (Fig. 4). Concentration of inorganic nutrients show signs of replenishment in the upper layer during autumn, increasing by $1-3 \mathrm{mmol} \mathrm{m}^{-3}$ on average over the section, with the largest percent change occurring over the GBS (Table 3). The autumn inventories for inorganic nutrients over the FC and SL waters show little change compared to levels observed during summer, but are substantially elevated on the GBS (Table 4).

Overall, there has been a decrease in phytoplankton biomass across the section during autumn since 2000, 

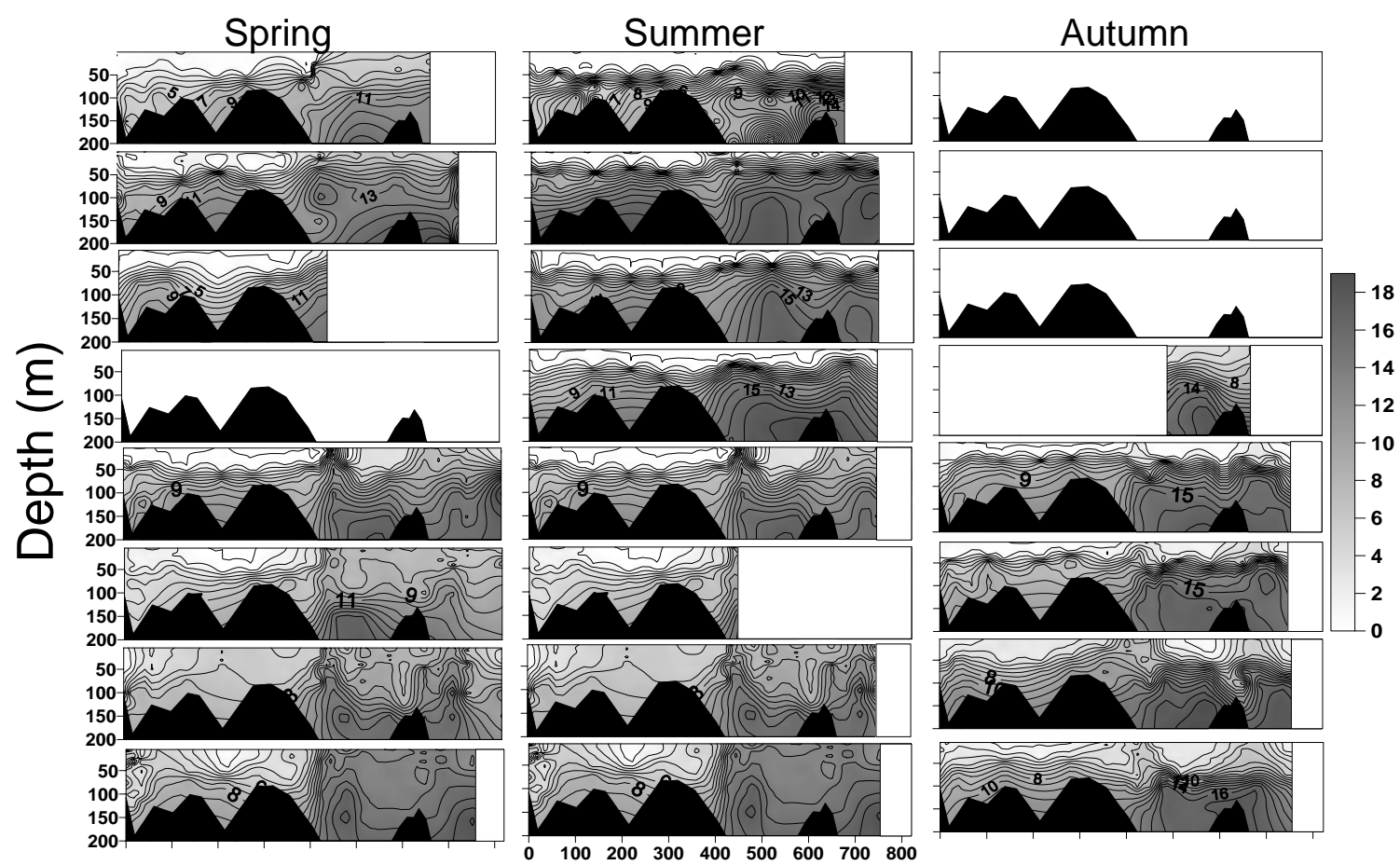

\section{Distance from Inshore Station (Km)}

Fig. 4. The seasonal vertical profiles of nitrate (nitrate + nitrite combined; $\mathrm{mmol} \mathrm{m}^{-3}$ ) in the upper $200 \mathrm{~m}$ versus distance from the inshore coastal station across the Flemish Cap section during 1996-2003 (chronology starting from the top panels). Bottom bathymetry shown in solid black. Rectangular whited out regions indicate no data available.

TABLE 3. Seasonal average $( \pm \mathrm{SD})$ of nutrient (nitrite + nitrate; $\mathrm{NO}_{3}$, and silicate; $\mathrm{SiO}_{4}$ ) and chlorophyll $a$ concentrations in the upper $75 \mathrm{~m}$ along the Grand Bank Shelf (GBS), Flemish Cap (FC) and Slope (SL) waters during 1996-2003.

\begin{tabular}{llccc}
\hline \hline Season & Location & $\begin{array}{c}\text { Avg. } \mathrm{NO}_{3} \\
\left(\mathrm{mmol} \mathrm{m}^{-3}\right)\end{array}$ & $\begin{array}{c}\text { Avg SiO } \\
\left(\mathrm{mmol} \mathrm{m}^{-3}\right)\end{array}$ & $\begin{array}{c}\text { Avg Chla } \\
\left(\mathrm{mg} \mathrm{m}^{-3}\right)\end{array}$ \\
\hline Spring & GBS & $2.57 \pm 2.72$ & $2.35 \pm 2.56$ & $3.11 \pm 2.34$ \\
& SL & $8.68 \pm 3.53$ & $5.48 \pm 2.32$ & $2.16 \pm 2.01$ \\
Summer & FC & $7.66 \pm 3.70$ & $5.60 \pm 2.99$ & $2.42 \pm 2.05$ \\
& GBS & $1.81 \pm 2.94$ & $1.82 \pm 2.70$ & $0.61 \pm 1.25$ \\
Autumn & SL & $3.78 \pm 4.64$ & $2.13 \pm 2.61$ & $0.94 \pm 1.05$ \\
& FC & $3.09 \pm 4.66$ & $2.02 \pm 2.35$ & $0.89 \pm 1.26$ \\
& GBS & $3.24 \pm 2.94$ & $4.04 \pm 3.07$ & $0.54 \pm 0.49$ \\
& SL & $4.87 \pm 3.43$ & $2.72 \pm 1.72$ & $0.71 \pm 0.49$ \\
& FC & $4.10 \pm 3.35$ & $2.55 \pm 1.63$ & $1.11 \pm 1.03$ \\
\hline
\end{tabular}

with enhanced localized blooms confined in recent years to the eastern GBS, FC and SL waters (Fig. 5). The concentrations of chlorophyll $a$ are found in surface waters with no evidence of subsurface DCM layers forming as observed during spring and summer occupations. The autumn chlorophyll $a$ concentrations in the upper layer were very similar to levels observed during summer with values near $1 \mathrm{mg} \mathrm{m}^{-3}$ across the section (Table 3 ). Overall, the chlorophyll $a$ inventories during autumn remain higher on the FC and SL waters then on the GBS (Table 4). 
TABLE 4. Seasonal average $( \pm \mathrm{SD})$ of integrated (0-75 $\mathrm{m}$ integral) nutrients (nitrite + nitrate; $\mathrm{NO}_{3}$ and silicate; $\mathrm{SiO}_{4}$ ) and chlorophyll $a$ inventories during 1996-2003 along the Grand Bank Shelf (GBS), Flemish Cap (FC) and Slope (SL) waters. Depth of the nitracline is defined as the depth in which nitrate concentration exceeds $0.5 \mathrm{mmol} \mathrm{m}^{-3}$, which forms prominently during the summer stratification maximum.

\begin{tabular}{llcccc}
\hline \hline Season & Location & $\begin{array}{c}\mathrm{Avg.} \mathrm{NO}_{3} \\
\left(\mathrm{mmol} \mathrm{m}^{-2}\right)\end{array}$ & $\begin{array}{c}\mathrm{Avg} \mathrm{SiO}_{4} \\
\left(\mathrm{mmol} \mathrm{m}^{-2}\right)\end{array}$ & $\begin{array}{c}\text { Avg Chla } \\
\left(\mathrm{mg} \mathrm{m}^{-2}\right)\end{array}$ & $\begin{array}{c}\text { Nitracline } \\
(\mathrm{m})\end{array}$ \\
\hline Spring & GBS & $214.9 \pm 96.0$ & $193.5 \pm 135.2$ & $230.5 \pm 139.4$ & \\
& SL & $520.1 \pm 137.6$ & $434.8 \pm 105.5$ & $149.0 \pm 99.3$ & \\
& FC & $455.1 \pm 142.7$ & $427.6 \pm 134.6$ & $166.7 \pm 97.7$ & \\
\multirow{3}{*}{ Summer } & GBS & $199.1 \pm 58.9$ & $162.5 \pm 85.7$ & $53.1 \pm 53.6$ & $48.5 \pm 8.7$ \\
& SL & $349.7 \pm 165.3$ & $192.8 \pm 74.3$ & $70.8 \pm 34.8$ & $31.7 \pm 8.1$ \\
& FC & $295.3 \pm 145.1$ & $178.3 \pm 100.8$ & $64.6 \pm 39.4$ & $38.0 \pm 10.8$ \\
& & & & & \\
& GBS & $270.1 \pm 64.5$ & $334.9 \pm 103.3$ & $35.4 \pm 18.4$ & \\
& SL & $340.3 \pm 81.2$ & $214.3 \pm 75.4$ & $48.9 \pm 20.2$ & \\
& FC & $314.5 \pm 58.5$ & $199.5 \pm 70.9$ & $76.4 \pm 50.3$ & \\
\hline
\end{tabular}

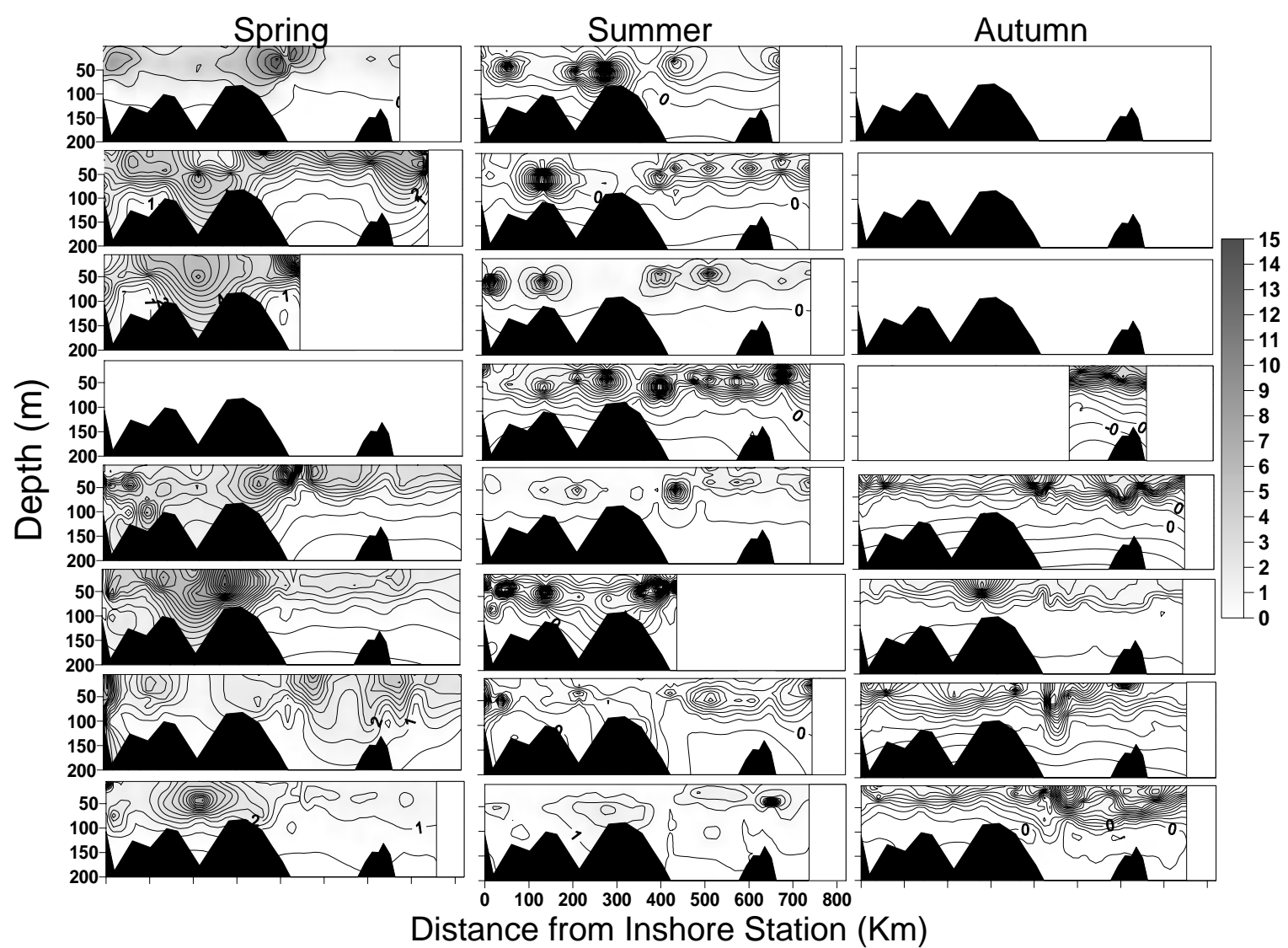

Fig. 5. The seasonal vertical profiles of chlorophyll $a\left(\mathrm{mg} \mathrm{m}^{-3}\right)$ in the upper $200 \mathrm{~m}$ versus distance from the inshore coastal station across the Flemish Cap section during 1996-2003 (chronology starting from top panels). Bottom bathymetry shown in solid black. Rectangular whited-out regions indicate no data available. 
The relationship between dissolved concentrations of nitrate and silicate provides information regarding the relative importance in utilization of inorganic nutrients and their depth-dependent distribution across the section. The proportion of nitrate to silicate is roughly equal on the GBS during spring and summer, while during autumn there is more dissolved inorganic silicate present than nitrate on average (Fig. 6). The seasonal nutrient relationships on the GBS suggest that both inorganic nutrients are important to the phytoplankton assemblage from the onset of the production cycle in the spring through summer, but nitrate may be more limiting during autumn. The FC and SL waters are more replete in nitrate in contrast to lower concentrations of silicate during the seasonal occupations (Fig. 6). The differential removal of silicate and nitrate is evident during the production cycle on the $\mathrm{FC}$ and $\mathrm{SL}$ waters. The relationship between nitrate and silicate on the FC and SL waters does not follow the linear pattern observed on the GBS, particularly during the summer and autumn periods (Fig. 6). The evolution of the seasonal nutrient relationships on the FC and SL waters indicate differential utilization of these dissolved nutrients between the mid to late production cycle and suggest that nitrate is the main limiting nutrient.

\section{Biological Conditions - Phytoplankton Composition, Biomass, and Productivity}

The community composition and abundance of diatoms, which represent an important phytoplankton group during the spring and autumn blooms in the northwest Atlantic given their relatively large size, were dominated by several different species across the section. The main diatom taxa over the GBS consisted of Thalassiosira sp., Chaetoceros sp., Ceratium sp., and Thalassiothrix sp., while Thalassiosira sp. clearly dominated and Ceratium sp. were largely absent over the FC and SL waters (Table 5 ). The examination of all major phytoplankton classes in 2003, including the diatoms, dinoflagellates, and flagellate taxa, indicates seasonal shifts in community composition across the section. The percentage contribution of major taxa during spring indicated that diatoms (Chaetoceros and Thalassiosira sp.) dominant the GBS, but shifted to a flagellate (mainly unidentified genera) and dinoflagellate (Prorocentrum, Gonyaulux, and Gymnodinium) community over the FC and SL waters (Table 5). Most of the flagellate genera could not be identified due to their small size. Those genera that could be identified consisted mainly of coccolithophorids. The loss of diatoms is

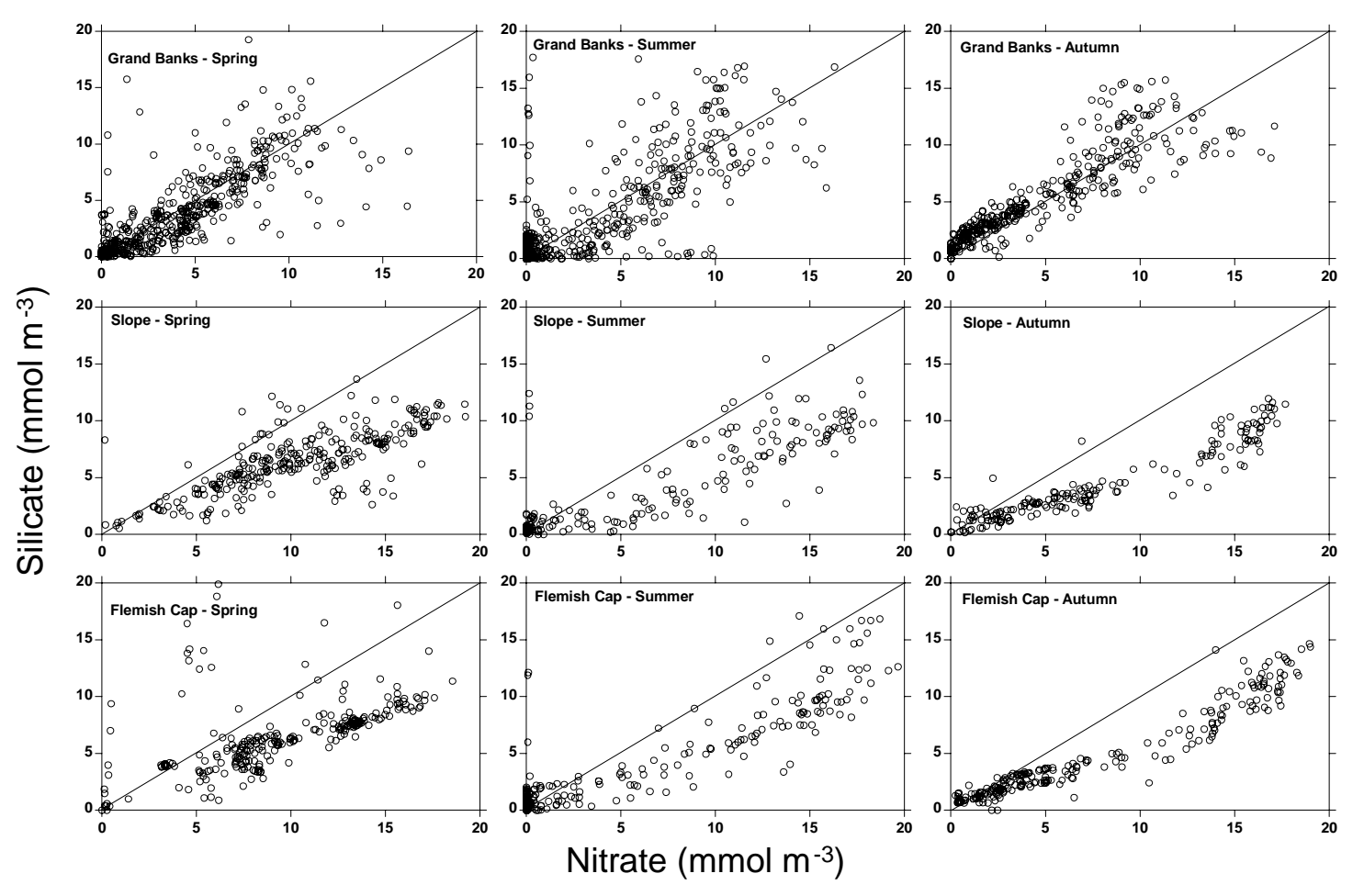

Fig. 6. Plots of nitrate (combined nitrite and nitrate) versus silicate for all depths sampled across the Flemish Cap oceanographic section during 1996-2003. The 1:1 line is provided for reference. 
TABLE 5. The percentage contribution of major phytoplankton genera enumerated across the Flemish Cap section by the Atlantic Zonal Monitoring Program (spring, summer, and autumn occupations) in 2003 and Continuous Plankton Recorder (CPR) Survey in NAFO Div. 3LNO (Grand Banks) and Div. 3M (Flemish Cap). See Fig. 2 for distribution of CPR data.

\begin{tabular}{|c|c|c|c|c|c|}
\hline $\begin{array}{l}\text { Phytoplankton } \\
\text { Genera }\end{array}$ & $\begin{array}{c}\text { Grand Bank } \\
\text { Shelf } \\
\text { AZMP }\end{array}$ & $\begin{array}{c}\text { Slope } \\
\text { AZMP }\end{array}$ & $\begin{array}{c}\text { Flemish Cap } \\
\text { AZMP }\end{array}$ & $\begin{array}{c}\text { Grand Banks } \\
\text { (Div. 3LNO) } \\
\text { CPR }\end{array}$ & $\begin{array}{c}\text { Flemish Cap } \\
\text { (Div. 3M) } \\
\text { CPR }\end{array}$ \\
\hline Diatoms & - & - & - & - & - \\
\hline Chaetoceros & $16,0,0$ & - & - & 38 & 16 \\
\hline Coscinodiscus & - & - & - & 2 & - \\
\hline Fragilaria & - & - & - & 2 & 8 \\
\hline Pseudo-Nitzschia & - & - & $0,0,78$ & - & 3 \\
\hline Rhizosolenia & - & - & - & 2 & 2 \\
\hline Thalassionema & - & - & - & 2 & - \\
\hline Thalassiosira & $40,0,0$ & - & - & 26 & 56 \\
\hline Thalassiothrix & $3,0,0$ & - & - & 10 & 11 \\
\hline Neodenticulata & - & - & - & - & - \\
\hline Pennate & - & - & $5,0,0$ & - & - \\
\hline Dinoflagellates & - & - & - & - & - \\
\hline Ceratium & - & - & - & 21 & 1 \\
\hline Gonyaulax & - & $3,0,0$ & $0,9,0$ & - & - \\
\hline Gymnodinium & $2,4,7$ & $6,16,0$ & $9,12,0$ & - & - \\
\hline Heterocapsa & - & - & - & - & - \\
\hline Prorocentrum & $3,0,0$ & $14,0,0$ & $7,0,0$ & - & - \\
\hline Flagellates & - & - & - & - & - \\
\hline Coccolithophorid & - & $4,0,0$ & $2,0,0$ & - & - \\
\hline Coccoclithus & - & - & $5,6,0$ & - & - \\
\hline Emiliania & - & $7,5,3$ & $12,3,3$ & - & - \\
\hline Leucocryptos & - & $2,0,0$ & - & - & - \\
\hline Dinobyron & $0,18,0$ & - & - & - & - \\
\hline Plagiotropis & $3,0,4$ & - & - & - & - \\
\hline Chrysophyte Cysts & - & - & - & - & - \\
\hline Hillea & - & - & $0,3,0$ & - & - \\
\hline Chrysochromulina & - & - & $0,3,0$ & - & - \\
\hline Pterospema & - & - & $0,3,0$ & - & - \\
\hline Dentonula & - & - & - & - & - \\
\hline Silicoflagellates & - & - & - & 2 & - \\
\hline \multicolumn{6}{|l|}{ Unidentified } \\
\hline Flagellates & $26,34,58$ & $59,47,6$ & $60,60,11$ & - & - \\
\hline
\end{tabular}

evident, together with a shift to a community composed of small flagellate cells, along with a contribution of larger dinoflagellate genera across the section during summer (Table 5). An unusual mono-specific bloom of Pseudonitzschia sp. (diatom) over the FC and SL waters was observed during the autumn survey in 2003, but did not impact the GBS, that was dominated by flagellate genera (Table 5, Fig. 5).

Satellite imagery highlight the difference in the duration and spatial extent of surface blooms across the northwest Atlantic. SeaWiFS bi-weekly composite images of ocean colour indicate that surface phytoplankton blooms begin to form during early March, peak in mid to late April, and diminish rapidly by early May across the GBS (Fig. 7). In contrast, surface blooms on the FC and SL waters are generally initiated at about the same time but extend well into the June-July months compared to the early cessation on the GBS by early May (Fig. 7). Thereafter, extensive surface blooms are limited to locations further north along the Labrador Shelf. Cell counts of major phytoplankton genera (enumerated directly by 

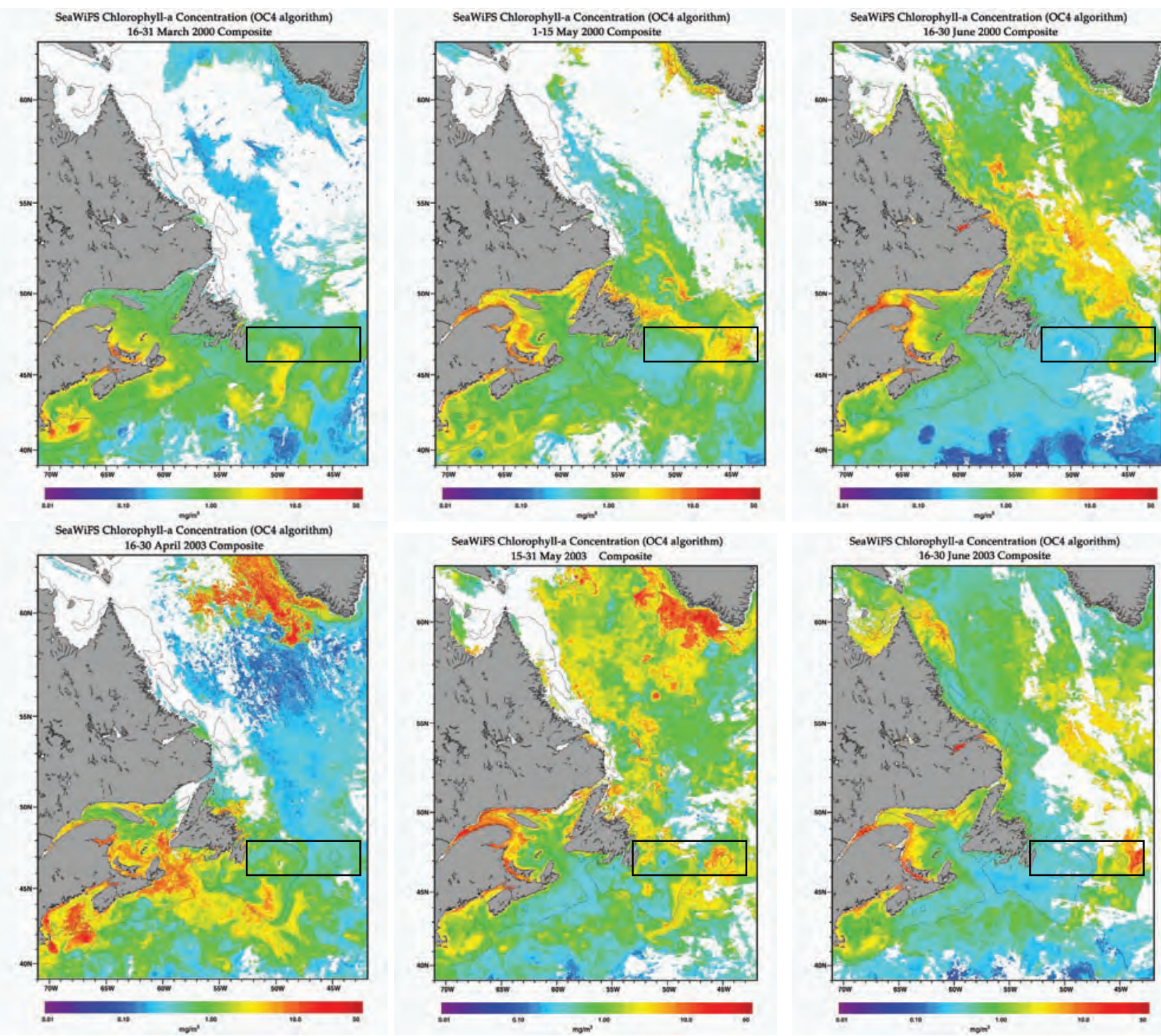

Fig. 7. SeaWiFS bi-weekly ocean colour imagery for the Northwest Atlantic zone in year 2000 (top panels), an example of an early bloom, and year 2003 (bottom panels), an example of a delayed bloom during the main production cycle (March-June). The $200 \mathrm{~m}$ isobath contour is provided showing the Grand Banks and Flemish Cap region near $47^{\circ} \mathrm{N}$ latitude, $45^{\circ} \mathrm{W}$ longitude. Rectangular areas are provided to highlight the area surrounding the Flemish Cap oceanographic section. SeaWiFS chlorophyll $a$ concentration ranges from 0.01 (violet) to 50 (red) in units of $\mathrm{mg} \mathrm{m}^{-3}$.

microscopy) during seasonal occupations of the section indicate 3 -fold higher cell counts in SL waters at $1.5 \times 10^{5}$ cells $\mathrm{L}^{-1}$ versus ca. $5 \times 10^{4}$ cells $\mathrm{L}^{-1}$ on the GBS and FC. Cell counts were enhanced 5-fold at $5 \times 10^{5}$ cells $\mathrm{L}^{-1}$ on the FC versus $1 \times 10^{5}$ cells $\mathrm{L}^{-1}$ on the GBS and SL waters during summer. Higher cell counts were also observed on the FC at $2.5 \times 10^{5}$ cells $\mathrm{L}^{-1}$ versus $5.0 \times 10^{4}$ cells $\mathrm{L}^{-1}$ on the GBS and SL waters during autumn. Enhanced rate processes such as primary productivity may contribute to the observed differences in the cell counts of major phytoplankton genera across the section. The rate of in- tegrated primary production determined from ${ }^{14} \mathrm{C}$-uptake experiments conducted during the autumn occupations of the section is greater on the FC $\left(404.1 \pm 174.6 \mathrm{mg} \mathrm{C} \mathrm{m}^{-2}\right.$ $\mathrm{d}^{-1}$, (mean of autumn 2000-03 \pm SD) and SL waters (483.1 $\pm 307.7)$ compared to the GBS (358.4 \pm 156.1$)$ and inshore coastal (Station 27) station (220.1 \pm 68.2$)$.

Seasonal and interannual changes in the nutrient pools provide a bulk measure of the potential and magnitude in primary production across the section. Changes in the seasonal averaged nutrient inventories during 1996-2003 
from the spring to summer indicated a small draw down on the GBS (net changes of -15 and $-30 \mathrm{mmol} \mathrm{m}^{-2}$; nitrate and silicate respectively) compared to a large draw down on the FC (-160 and $\left.-170 \mathrm{mmol} \mathrm{m}^{-2}\right)$, and SL waters $\left(-250\right.$ and $-240 \mathrm{mmol} \mathrm{m}^{-2}$ ) (Table 4). Using an average winter value of $300 \mathrm{mmol} \mathrm{m}^{-2}$ for nitrate obtained from the inshore coastal Station 27 as a proxy for conditions on the GBS, suggests some limited biological uptake has occurred prior to sampling (Fig. 8). This would support the suggestion that phytoplankton blooms may propagate from the inner to the outer Shelf and the bulk of the production on the FC and SL waters occurs somewhat later in the season. The large draw down of silicate on the FC and SL waters suggests that siliceous phytoplankton are an important component of the community in the offshore. During the summer to autumn transition, nutrient replenishment of $+80 \mathrm{mmol} \mathrm{m}^{-2}$ and $+175 \mathrm{mmol} \mathrm{m}^{-2}$ occurs on the GBS, while the changes on the FC and SL waters are marginal for both nutrients (Table 4). The lack of nutrient regeneration on the $\mathrm{FC}$ at this time suggests a continuing higher rate of primary production compared to the GBS. The major replenishment of nutrients on the FC and SL water occurs over winter (autumn to spring transition) with large increases in inventories of +140 and $+230 \mathrm{mmol} \mathrm{m}^{-2}$ (FC), and 180 and $220 \mathrm{mmol} \mathrm{m}^{-2}$ (SL), in contrast to the GBS where a draw down of -55 and -145 $\mathrm{mmol} \mathrm{m} \mathrm{m}^{-2}$ is observed. The differential replenishment of nutrients on the FC and SL waters versus draw down on
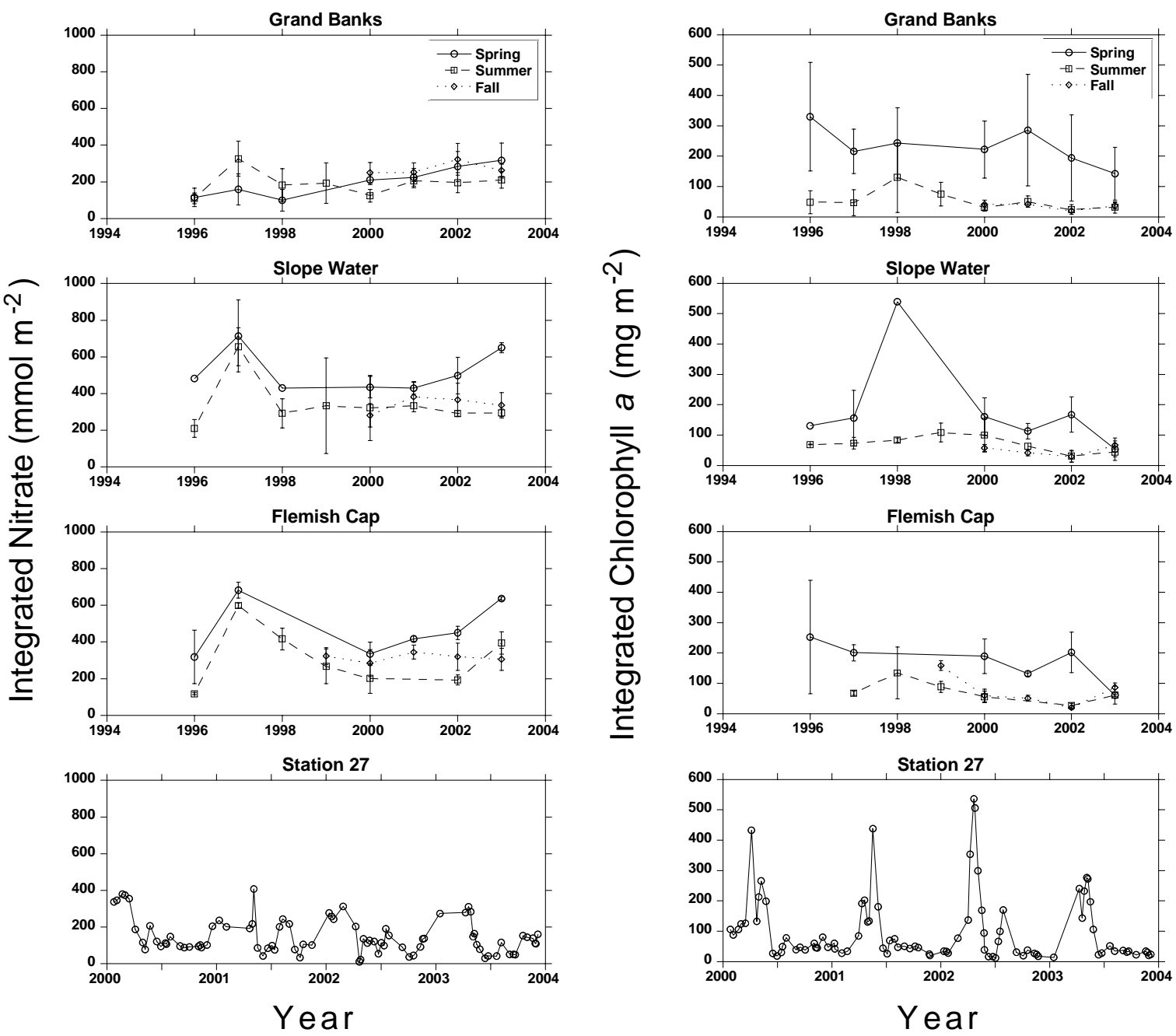

Fig. 8. Seasonal and interannual variability in nitrate (nitrate and nitrite combined) and chlorophyll $a$ inventories (0-75 m integral) across the Flemish Cap section during 1996-2003. Note that data is not available during some seasons and years for both nitrate and chlorophyll $a$ inventories. Bottom panels show comparison of seasonal and interannual variability in nitrate and chlorophyll $a$ inventories $(0-75 \mathrm{~m}$ integral) from inshore fixed coastal station (Station 27) during bi-weekly-monthly monitoring from 2000-04. 
the GBS during this transition, further supports the notion of an earlier spring bloom inshore on the continental Shelf compared to the offshore. The seasonal and interannual variability in nitrate and chlorophyll a inventories across the FC section suggests that differences in recent years have been relatively consistent since the mid-1990s (Fig. 8). One notable exception was the elevated nitrate inventories observed on the FC and SL waters during the spring and summer occupations in 1997 compared to the GBS (Fig. 8).

\section{Biological Conditions - Zooplankton Biomass and Composition}

Plankton data from the CPR are used to investigate the zooplankton community composition and abundance trends across the GBS, FC, and SL waters. The major zooplankton taxa were dominated by copepods for both the GBS and FC and SL waters. Copepod genera accounted for ca. $70 \%$ of all zooplankton numerically (Table 6). While larger Calanoid (C. finmarchicus, C. glacialis, and C. hyperboreus) copepods clearly dominate the community on the FC, smaller copepods (Paracalanus/Pseudocalanus and Oithona sp.) are more abundant on the GBS (Table 6). Larger macro-invertebrate groups consisting of important prey and predators (e.g. Hyperiidea and Euphausiacaea) accounted for the remainder of the community composition. One icthyoplankton group, consisting of early life stages of Sebastes spp. (larval redfish) accounted for a small percentage of the community on both the FC and GBS (Table 6).

Given the importance of copepods in the community composition of zooplankton, the seasonal and annual trends in abundance of Copepoda (all copepods combined) were investigated across the section. The timing of peak abundance of copepods is later (peak in late autumn) on the GBS in contrast to a less-pronounced seasonal cycle on the FC and SL waters (Fig. 9). Trends in the annual abundance of copepods suggest relatively stable populations during the available time series of the CPR (Fig. 9). The overall trend for Div. 3LNO (GBS) indicated a slight negative trend from the 1960-70s and through the 1990s, while in Div. 3M (FC and SL) the trend was positive through the 1960-70s and overall slightly lower through the 1990s. The numerical abundance of copepods is ca. $50 \%$ higher $\left(150 \mathrm{~m}^{-3}\right)$ on the GBS compared to $100 \mathrm{~m}^{-3}$ on the FC and SL waters. Although the numerical abundance of copepods is greater on the GBS, many of the dominant species are substantially smaller in body size compared to the assemblage on the FC. The relatively large differences in body sizes of the dominant copepods suggests that the FC supports higher biomass levels compared to the GBS. Dry weight estimates of C. finmarchicus, C. glacialis, C. hyperboreus, Pseudocalanus /Paracalanus spp., and

TABLE 6. Percentage contribution of major zooplankton genera enumerated by the Continuous Plankton Recorder (CPR) survey in NAFO Div. 3LNO (Grand Banks) and Div. 3M (Flemish Cap). See Fig. 2 for locations of the CPR survey.

\begin{tabular}{lcc}
\hline \hline Zooplankton Genera & Grand Banks (3LNO) & Flemish Cap (3M) \\
\hline Bivalvia & 1 & - \\
Calanus finmarchicus & 7 & 48 \\
C. glacialis & - & 1 \\
C. hyperboreus & - & 2 \\
Centropages hamatus & 3 & - \\
Chaetognatha & - & 3 \\
Cirripedia & 9 & - \\
Echinodermata & 1 & - \\
Euchaeta & - & 1 \\
Evadne & 4 & - \\
Euphausiacea & 2 & 9 \\
Hyperiidea & - & 3 \\
Larvacea & 6 & 2 \\
Limacina & 4 & 5 \\
Metrida & - & 3 \\
Oithona & 23 & 7 \\
Paracalanus/Pseudocalanus & 26 & 11 \\
Sebastes & 2 & 4 \\
Temora longicornis & 8 & - \\
\hline
\end{tabular}



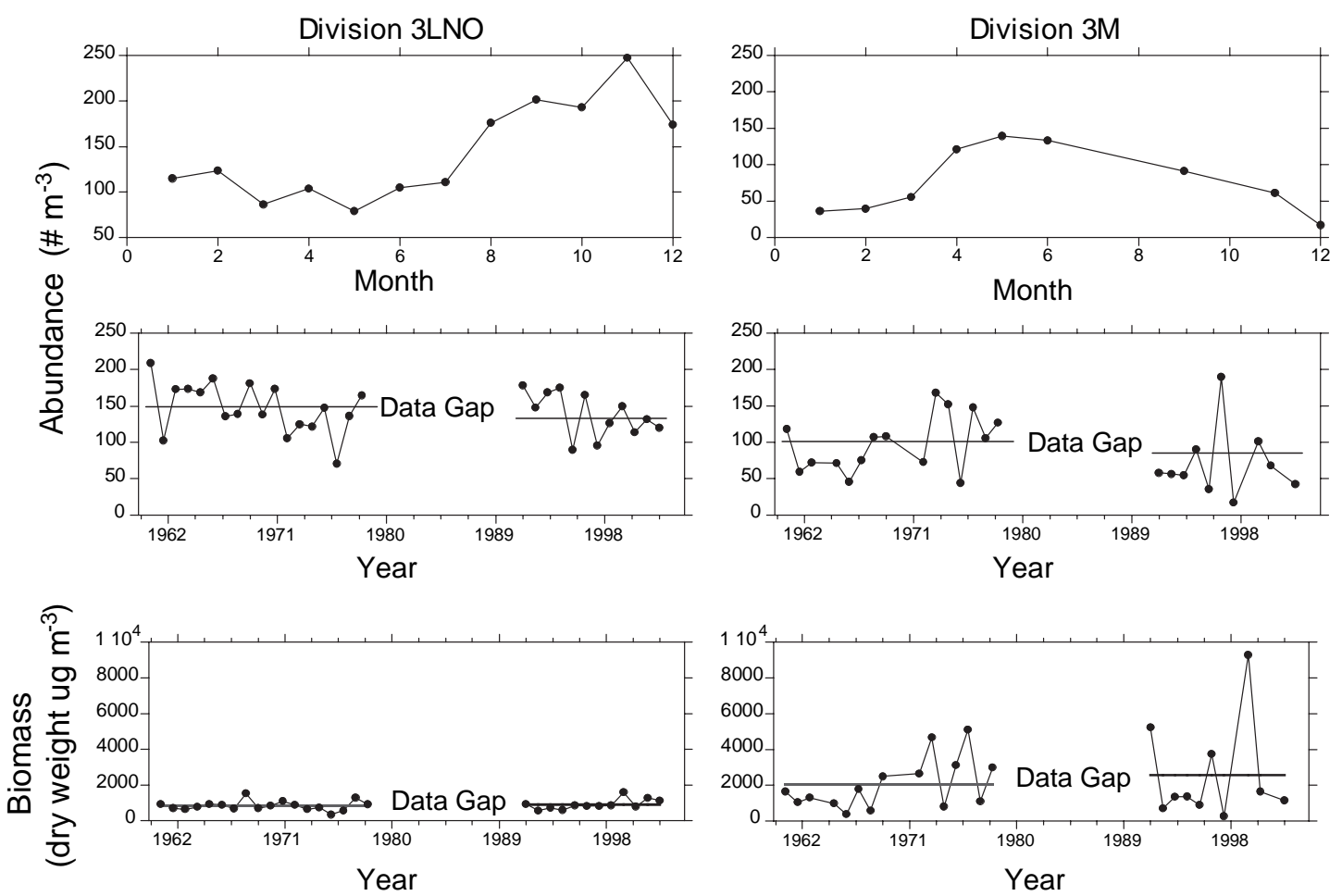

Fig. 9. The seasonal cycle and annual abundance and trends in Copepoda (all copepods combined) enumerated by the Continuous Plankton Recorder (CPR) Program during 1961-78 and 1991-2002 in NAFO Div. 3LNO (Grand Banks) and Div. 3M (Flemish Cap). Corresponding biomass trends shown for dominant copepod species (C. finmarchicus, C. glacialis, C. hyperboreus, Pseudocalanus/Paracalanus sp., and Oithona sp.). See Fig. 2 for locations of the CPR survey.

Oithona sp. combined with the relative abundance estimates, show that the FC supports 2-fold higher biomass at ca. $2000 \mathrm{ug} \mathrm{m}^{-3}$ versus ca. $1000 \mathrm{ug} \mathrm{m}^{-3}$ ) on the GBS (Fig. 9). The biomass estimates indicate relatively stable levels on the GBS, while higher variability is observed on the FC. The trend in biomass on the FC indicates below average levels during the 1960s, shifting to above average levels during the 1970s, and below average biomasses through the 1990s with the largest variability observed during the later period (Fig. 9). The large variation observed in biomass within Div. 3M, particularly in 1999, was related to higher numerical abundance of Calanoid copepods C. finmarchicus and C. hyperboreus. Although numerical abundance was greater in 1997 in Div. 3M, this only resulted in an average level of biomass due to lower proportions of calanoid copepods versus the smaller Shelf species.

The trends in copepod assemblage and abundance across the section in 2003, from integrated vertical net tows, indicate that the small cyclopoid copepod Oithona sp. and Pseudocalanus/Paracalanus sp. are numerically dominant over the GBS, similar to the long-term pat- tern observed in the CPR data (Fig. 10). In the vicinity of the Shelf break, larger calanoid copepods such as C. finmarchicus dominate the assemblage, and become equally important with small copepods species over the FC and SL waters (Fig. 10). The numerical abundance of dominant copepods indicated higher levels on the GBS and SL waters during spring and autumn (Fig. 10). This trend is reversed during summer with peak concentrations reaching $6 \times 10^{5} \mathrm{~m}^{-3}$ located directly on the top of the FC, with relatively low abundance levels (ca. $0.5 \times 10^{5} \mathrm{~m}^{-3}$ ) distributed across the GBS (Fig. 10). The large change in community composition observed between autumn 2002 and 2003, may be related to the shift in timing of the surveys from early November to late November/early December, when calanoid copepods may begin diapause and sink to deeper waters.

Using the dry weight conversion parameters for the dominant copepod taxa, the importance of the large calanoid forms in dominating the biomass pattern across the section becomes apparent (Fig. 10). During spring copepod species C. hyperboreus and C. finmarchicus clearly dominate the biomass from the outer Shelf and 

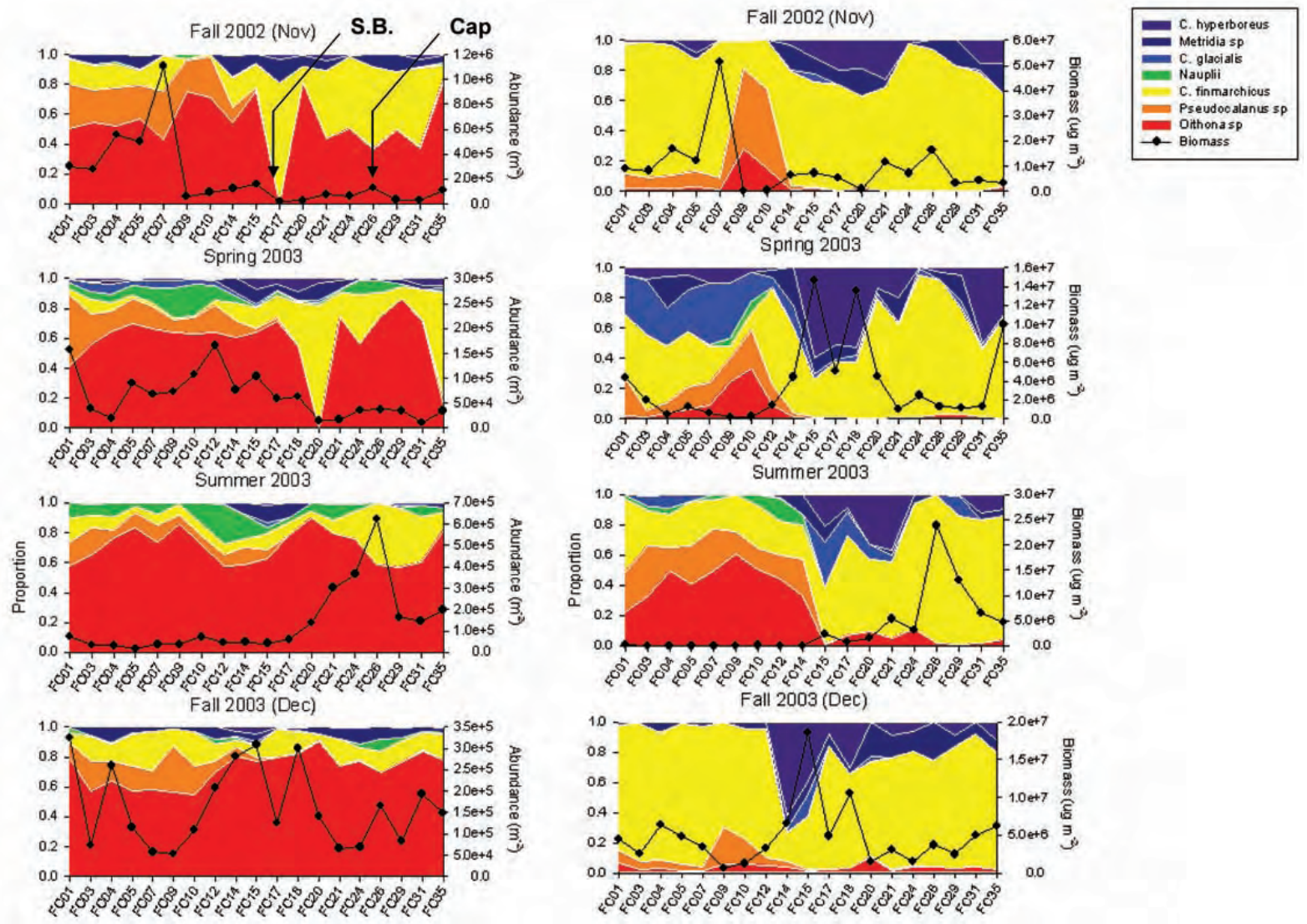

Fig. 10. Percentage contribution, numerical abundance, and biomass of major copepod genera enumerated by the Atlantic Zonal Monitoring Program along the Flemish Cap oceanographic section during 2002-03. The Grand Banks Shelf occupies station's FC-01 to FC-15, Slope waters ( $>500 \mathrm{~m})$ from FC-16 to FC-19, and FC-31 to FC-35, while the Flemish Cap ( $<500 \mathrm{~m})$ from FC-20 to FC-30. The approximate location of the Shelf Break (S.B.) and the top of the Flemish Cap (Cap) are provided in the upper left panel.

across the FC and SL waters (Fig. 10). The other large calanoid C. glacialis, appears to be largely confined to the GBS along with the smaller copepods Pseudocalanus/Paracalanus and Oithona sp. During summer, small copepods make up a large proportion of the assemblage over the GBS, but peak biomass reside over the FC and are dominated by C. finmarchicus and C. hyperboreus (Fig. 10). Despite the low numerical abundance of calanoid copepods observed during the autumn 2003 survey compared to the previous year, C. finmarchicus and C. hyperboreus clearly dominate the community in terms of biomass across the entire section (Fig. 10).

\section{Discussion}

Significant differences in the thermohaline properties and distribution of inorganic nutrients were apparent across the FC section during the seasonal occupations. In contrast to the GBS, the nutrient concentrations observed over the FC and adjacent SL waters are consistently elevated. The actual mechanism for this nutrient enrichment has not been identified but may result from the entrainment of water from the NAC over the FC and SL waters through baroclinic instability or other mechanisms (Wright, 1987). The thermohaline properties over the FC indicate entrainment of North Atlantic water as the likely mechanism for nutrient enhancement in this region. Additional contribution of nutrients through vertical advective and mixing processes linked to the geostrophic flow of major current systems surrounding this region may also be important given the shallow water and steep gradients in SL waters surrounding this submarine bank (Colbourne and Foote, 2000; Loder et al., 1988, Yentsch, 1980). Elevated inventories of nutrients observed in 1997 on the FC and SL waters indicate the importance of volume transport of the LC. Variability in the LC based on satellite altimetry data indicated an intensification over the Newfoundland Slope during 1996-97 (Han and Li, 2004).

Relative changes in the nitrate and silicate pools on the FC and SL waters showed a 10-fold reduction in concentrations during the transition from spring to sum- 
mer compared to that observed on the GBS. The large difference in inventories during this seasonal transition would suggest substantially higher primary production (via biological uptake by phytoplankton) on the FC and SL compared to the GBS, but we cannot rule out the contribution of water mass exchange through horizontal and vertical fluxes. Similar changes in nutrient dynamics have been observed on the Scotian Shelf and in the Gulf of Maine and have been linked to several factors including the timing of the production cycle, enhanced vertical supply of nutrients through mixing or upwelling processes; inadequate sampling during winter; and advective export sources (Petrie and Yeats, 2000). Our interpretation however, is that the small change in nutrient inventories observed on the GBS during transition from spring to summer may be related to the early onset of the production cycle on the Shelf whereby biological uptake has already begun by the time of spring sampling. This interpretation is supported by the early production of diatoms observed by the AZMP (Pepin et al., MS 2004). Earlier studies have demonstrated that the spring phytoplankton bloom develops later on the FC compared to the GBS (Anderson, 1990), and changes in nutrient inventories during the seasonal transitions would lend support to this general observation. Differences were also noted during the transition from summer to autumn, where nutrient replenishment (net change) is greater on the GBS compared to the small change on the FC and SL waters. This might indicate a small, but significant level of primary production continuing on the $\mathrm{FC}$ and SL versus lower rates on the GBS. One might argue that changes in mixing across the section may also contribute to the observed differences, but this does not appear to be the case based on stratification and mixed layer depth indices. Changes in the nutrient pools during transition from autumn to spring suggested that the bulk of nutrient replenishment occurs on the FC and SL region over winter, with inventories of nitrate and silicate reaching maximal levels. In contrast to conditions on the FC, depleted levels of nutrients are observed on the GBS, particularly in the case of silicate, providing further evidence for the early production of diatoms during the spring bloom.

Many of the main phytoplankton genera were distributed over much of the section, the exception being the subarctic genera Ceratium, which contributes significantly to the community composition on the GBS but apparently not on the FC. The lack of this subarctic genera on the FC may be related to the elevated temperatures in this region during winter and early spring due to the influence of the NAC, compared to lower temperatures experienced over the GBS. The major phytoplankton taxa observed across the section in 2003 indicate spatial and seasonal shifts in community composition. While large-celled diatoms dominant the phytoplankton assemblage on the GBS during spring, they are largely absent on the FC and SL where smaller phytoplankton cells, principally flagellate and dinoflagellate genera dominated. The large draw down of both nitrate and silicate inventories on the FC and SL during the spring through the autumn transition indicates a delayed onset of diatom production, and perhaps silicoflagellates, but a prolonged production cycle fueled by transport of inorganic nutrients from depth that may potentially result in larger amounts of energy transfer to the benthos compared to the GBS. Large-scale blooms of pennate diatoms have been recently documented impacting a large area over the FC and SL waters in the autumn of 2003. The large bloom of Pseudo-Nitzschia sp. observed in the autumn of 2003 across the FC and SL waters has also been observed in recent years in the southern North Sea (Edwards et al., 2004). This species is of particular importance since it is associated with harmful algal blooms and the occurrence of amnesic shellfish poisoning.

The biological uptake of inorganic nutrients by phytoplankton and the timing of the spring bloom are consistent with SeaWiFS imagery and in-situ observations (Pepin et al., MS 2004). Since 1996, our results indicate that most of the chlorophyll $a$ concentration during spring is confined to the GBS and SL waters, while concentrations are lower across the FC. However, differences in timing between surveys and changes in the production cycle can not be discounted and may also contribute to the observed patterns in biomass across the section. We could not resolve any major shifts in the initiation of surface blooms across the FC section based on the SeaWiFS bi-weekly ocean colour images other than the latitudinal gradients from south to north. The satellite imagery does not capture sub-surface blooms, but does provide evidence of longer duration surface blooms across the FC and SL waters, well beyond the cessation of production by early May observed on the GBS. Evidence of enhanced productivity on the FC and adjacent waters captured by satellite remote sensing, is likely the result of higher nutrient inventories in this region. At this time we cannot differentiate between localized versus advective processes as the mechanism responsible for this enhancement.

The extensive consumption of the nitrate during the seasonal production cycle of phytoplankton along the section leads to the formation of the nitracline. The depth of the nitracline varied across the section with deeper levels observed over the GBS, in contrast to shallower levels over the FC and SL waters during summer. The depth of the nitracline shoaled by 10-20 m over the FC and SL, compared to the average level observed over the GBS. This will have an important potential implication on the 
rate of "new production" fueled from transport of nitrate from depth into the euphotic zone versus "regenerated production" based on recycled nutrients (e.g. ammonia). Although we have not yet calculated the nitrate flux into the euphotic zone across the section, the vertical gradients along with the depth of the nitracline indicate the potential for substantially higher flux to the FC and SL waters compared to more highly stratified conditions on the GBS.

Changes in the community composition, along with associated differences in numerical abundance and biomass of zooplankton were evident across the section. Data from the CPR surveys indicate the numerical dominance of copepods over the section. However, many of the dominant species on the GBS are substantially smaller in body size relative to species found on the FC and SL waters. Although the numerical abundance of the cyclopoid copepod Oithona sp. is very high on the GBS, the large calanoid genera dominate the biomass pattern across the section. During spring the subarctic species C. finmarchicus and C. hyperboreus clearly dominate the biomass from the outer Shelf and across the FC and SL waters. The other large calanoid C. glacialis, appears to be largely confined to the GBS along with smaller copepods Pseudocalanus/Paracalanus and Oithona sp. During summer small copepods make up a large proportion of the assemblage over the GBS but peak biomass levels reside over the FC and are dominated by $C$. finmarchicus and C. hyperboreus. Despite the low numerical abundance observed of these larger calanoid copepods during the autumn 2003 survey compared to the previous year, they clearly dominate the community in terms of biomass. The significance of these changes in body size, community composition and biomass of copepods may account for the finding that the growth rate of many invertebrate and fish species appears to be higher on the FC compared to the GBS, despite the relatively small distance between these areas (Bowering and Brodie, 1994; Morgan and Bowering, MS 2004). Feeding studies of early life stages of pelagic and demersal fish species indicate a strong preference for nauplii and copepodite stages of calanoid copepods, in contrast to a negative selection for nauplii and copepodite stages of cyclopoid copepods (e.g. Oithona sp.), one of the most numerically abundant species on the GBS (Pepin and Penney, 1997).

\section{Conclusions}

The shallow water of the FC, combined with the proximity of large-scale oceanic circulation around the Bank including the LC and NAC, which generate an anticyclonic gyre, elevate water temperatures, and entrain NAC water rich in inorganic dissolved nutrients, will have the potential to support higher primary and secondary production compared with the GBS. The southerly flow of the LC through the Flemish Pass and northeastern flank of the FC act to transport subarctic zooplankton species downstream from northern regions. Larger nutrient inventories observed on the FC and SL waters will provide the potential to support greater primary productivity compared to the GBS. Fluxes of "new" nitrogen (principally nitrate) delivered to the FC and SL waters appear to support significant levels of "new" primary productivity resulting in a higher productive capacity compared to the adjacent Shelf. The biomass estimates obtained from the dominant copepod genera from the CPR and AZMP surveys provide further evidence in support of higher primary productivity which may support greater secondary production over the FC and adjacent waters. The interannual variability in primary and secondary productivity, its dependence on nutrient dynamics and transport mechanisms over the GBS and the FC, remain an ongoing research effort as part of the AZMP.

\section{Acknowledgements}

Special thanks to T. Shears, E. Colbourne, C. Fitzpatrick, W. Bailey, P. Stead, D. Senciall, and C. Bromley for assistance at sea in the collection and processing of biological and physical oceanographic data, C. McKenzie for expertise in identification and enumeration of phytoplankton, M. Kennedy for provision of CPR data, Staff at the Atlantic Reference Centre in St. Andrews for identification and enumeration of zooplankton, NWAFC Science Staff and Scientific Assistants and Coast Guard officers and crew for their assistance at sea. We are particularly indebted to M. Paranjape who led the early initiative to pursue plankton studies in the NW Atlantic. We thank Joanne Morgan, Brian Petrie, Jean-Claude Therriault and two anonymous reviewers for their comments and suggestions which greatly improved the manuscript.

\section{References}

ANDERSON, J. 1990. Seasonal development of invertebrate zooplankton on Flemish Cap. Mar. Ecol. Prog. Ser., 67: $127-140$.

BOWERING, W. R., and W. B. BRODIE. 1994. Distribution, age and growth and sexual maturity of American plaice (Hippoglossoides platessoides (Fabricius)) on Flemish Cap (NAFO Division 3M). J. Northw. Atl. Fish. Sci., 16: 49-61.

COLBOURNE, E. B., and K. D. FOOTE. 2000. Variability of the stratification and circulation on the Flemish Cap during the decades of the 1950s-1990s. J. Northw. Atl. Fish. Sci., 26: 103-122.

CRAIG, J. D. C., E. B. COLBOURNE, and G. L. MAILLET. MS 2001. Preliminary Studies of Density Stratification and 
Fluorescence on the Newfoundland Shelf. DFO Can. Sci. Adv. Sec. Res. Doc., No. 2001/085, 26 p.

CRAIG, J. D. C., and E. B. COLBOURNE. MS 2002. Trends in stratification on the Inner Newfoundland Shelf. DFO Can. Sci. Adv. Sec. Res. Doc., No. 2002/071, 15 p.

EDWARDS, M., A. RICHARDSON, S. BATTEN, and A. W. G. JOHN. 2004. Ecological Status Report: results from the CPR survey 2002/2003. SAFHOS Tech. Rep, 1: 1-8.

HAN, G., and J. Li. 2004. Sea surface height and current variability on the Newfoundland Slope from TOPEX/POSEIDON altimetry. Can. Tech. Rep. Hydrogr. Ocean Sci., 234 viii $+40 \mathrm{p}$.

LEWIS, M. R., and J. C. SMITH. 1983. A small volume, shortincubation time method for measurement of photosynthesis as a function of incident irradiance. Mar. Ecol. Prog. Ser., 13: 99-102.

LODER, J. W., C. K. ROSS, and P. C. SMITH. 1988. A spaceand time-scale characterization of circulation and mixing over submarine banks, with application to the northwestern Atlantic Continental Shelf. Can. J. Fish. Aquat. Sci. 45: 1860-1885.

MITCHELL M. R., G. HARRISON G, PAULEY, A. GAGNE, G. L. MAILLET, and P. STRAIN. 2002. Atlantic Zonal Monitoring Program sampling protocols. Can. Tech. Rep. Hydrogr. Ocean Sci., 223: 23 p.
MORGAN, M. J., and W. R. BOWERING. MS 2004. Is there mixing of American Plaice populations in the Flemish Pass? NAFO SCR Doc., No. 62, Serial No. N5023, 9 p.

PEPIN P., G. L. MAILLET, S. FRASER, and D. LANE. MS 2004. Biological and chemical oceanographic conditions on the Newfoundland Shelf during 2003. CSAS Res Doc., No. 2004/033, 55 p.

PEPIN, P., and R. W. PENNEY. 1997. Patterns of prey size and taxonomic composition in larval fish: are there general sizedependent models? J. Fish. Biol., 51(Suppl. A): 84-100.

PETRIE, B., and P. YEATS. 2000. Annual and interannual variability of nutrients and their estimated fluxes in the Scotian Shelf - Gulf of Maine region. Can. J. Fish. Aquat. Sci., 57: 2536-2546.

PLATT, T, and S. SATHYENDRANATH. 2000. Software for use in calculation of primary production in the oceanic water column. Biological Oceanography Division, Bedford Institute of Oceanography, Box 1006, Dartmouth, NS, Canada B2Y 4A2.

YENTSCH, C. S. 1980. Phytoplankton Growth in the Sea: A coalesence of disciplines. In: Primary Productivity in the Sea. P.G. Falkowski (ed.). Plenum Press, N.Y., p. 17-32.

WRIGHT, D. C. 1987. Baroclinic instability: Energy transfer and the role of potential vorticity conservation. Atmos. Ocean., 25(3): 225-241. 
